\title{
From the Indo-European Trickster to the Romanian Păcală; a comparative study
}

\author{
Ana R. Chelariu, ARA member \\ achelariu@,verizon.net \\ http://anarchelariu.wordpress.com
}

\begin{abstract}
The Trickster, as he is referred to in all the studies of mythology and folklore, is a fascinating character, whose function in the Indo-European social-cultural context is yet to be clarified. His presence is strongly visible from classic mythology to the recent folklore.

In mythology the Trickster is known as Hermes in the Greek heritage, Mercury in Roman culture, Loki in German sagas, Bricriu in the Irish songs, Pekulis/Patullos in the Baltic heritage, or Varuna in Hinduism.

In the European folklore the Trickster is found in each cultural complex: he is well known as Tyl Ulenspiegel in German countries, or Peik in Scandinavia, Pooca/Puca in Ireland, Velnius in the Baltic region, or Păcală in the Romanian tradition.

This paper will attempt to outline the Indo-European Trickster's traits as preserved in folklore particularly in the Romanian heritage.
\end{abstract}

\section{Trickster in Mythology}

According to Homer Hermes is the son of Zeus and Maia. Only a few hours old he steals Apollo's herds, and performs his first tricks: he wears huge sandals to hide his footprints, and makes all the cows walk backwards so that no one could tell where they are hidden. Then Hermes performs a significant ritual action: he sacrifices two cows, dividing the meat into twelve portions in honor of the twelve gods, but as the rules of sacrificial ritual require, he, as one of them, must not eat the flesh. He makes a fire by rubbing two laurel twigs, and cooks the meat. Although the aroma is appealing to him, he must restrain from eating. This episode explains why perhaps Hermes is often regarded as the god who taught people how to make fire. As the messenger of gods, master of the ancient mysteries of initiation, he is the instrument of transmitting the divine instructions to people. Returning home, he is no longer seen by humans, and dogs don't bark at him, signifying perhaps that his sacrificial act transformed him into the god that flies and can become invisible at wish [1].

Apollo's gratification for all his troubles is a musical instrument: a lyre, which makes beautiful sounds by the vibration of the air. In turn Apollo entrusts him with protecting his herds, thus confirming Hermes' position as the protector of shepherds, their flocks and the thieves.

Herodotus tells us that Hermes was regarded as a Pelasgian divinity of Thracian origin [2]. He was born in Arcadia, and particularly honored by the Arcadian shepherds as the protector of their flocks and huts. A rudimentary image of him was often found by the shepherds' doors as a symbol of veneration. This image was a bearded head pillar, and realistically modeled erect phallus. The phallus shaped stones or painted images are considered aggressive symbols of boundaries and fecundity. These 'hermai' are to be found in front of houses, in market places, but also at crossroads and at frontiers, signifying his role as the ethereal guide of the soul into the world of the dead.

The Lithuanian Pekulis, or the Prussian Patollus, are regarded as chthonic deities, agrarian helpers, who live near bodies of water. In the ancient times Pekulis was feared as the god of death. In the Christian era he was replaced by Velnias, the flying evil spirit, thus keeping the element of air as a medium and an attribute. According to Gimbutas [3], Velnias is a pastoral god, who helps the poor. He exhibits a perpetual resistance to Perkunas, the sovereign god As Hermes' symbol was a phallus, so Pekulis/Velnias 
often shows his enormous phallus to women. Velnias goes to weddings and frightens women who will not dance with him. He is known as the one who punishes the unfaithful. In a Prussian triptych Patullos is represented in the form of a horse's skull; his sacred objects are "the skulls of a man, a horse, and a cow" [4]. Velnias' parallel in the Old Russian is Veles or Volos, a god of horned cattle [5].

In Northern mythology Loki appears more as a companion of gods, and sometimes as a giant. He can change his sex and shape at will: in his female form he gives birth to monsters, thus causing considerable troubles for his companions. He is the 'mother' of Hell, the giantess who rules the realm of death. Loki scares the gods with old age and dying. He is an arch-thief stealing, or helping others to steal gods' treasures, and then helping the gods to recover them. In the poem "Lokasenna" [6] the gods try to keep him out of the hall of Aegir, where they are having a feast, but he manages to enter anyway. Once inside he betrays shameful secrets about the gods' cowardice and the goddesses' infidelities.

The Irish god Bricriu, whose nickname was Nemthenga, or Poison-Tongue, builds a splendid hall, preparing a feast to which he invites all the gods of Ulster. The gods refuse his invitation, but he threatens to make them kill each other, and to turn daughter against mother. After arriving at the party they try to keep him out of the hall, but he, as in the German version, manages to get in, and to incite the gods against one another. In the end, the hall is damaged, and he is covered with grime [7].

In the Indian mythology the pair Varuna and Mitra, have as their essential function to maintain the universal order. While Mitra looks after friendships and ratifies contracts, Varuna is the guardian of the oaths, upholds rtá the cosmic moral norm, thus he is the lord of moral order watching sinful behavior. He has ferocious, chaotic impulses if the rules are broken, punishing the guilty, actions that relate him to the Trickster character. Varuna is present at every gathering, witnesses every action. Varuna sees or 'shines' at night thus he is linked to the Moon, the place of the dead. He shares with Yama the title of King of the Dead. He regulates the motions of the heavens and the circulation of waters [8].

\section{Trickster in folklore: Romanian Păcală}

The Trickster from the folklore does not display major changes versus the mythological character. For comparison we will take the Romanian folk story of Păcală, and observe the corresponding motifs, as well as the differences.

In most of the Romanian folk tales anthologies the story starts with Păcală, the Trickster (Rom a păcăli 'to trick') who goes on top of a mountain, and builds a big fire, adding plenty of resin. A thick smoke rises up to God, who happens to have a cold. The smoke cures God's cold, who graciously offers Păcală anything he wants. The Trickster asks for a flute, a musical instrument very common among shepherds. The flute has magic powers; it makes anyone dance constantly until the music stops, as Pan's flute was making the satyrs and the fairies dance. Other mythical examples of this motif are Amphion, Orpheus, Oberon and Hameln, who are all creating magic with their musical instrument. The magic flute episode is found in Neo-Greek, Irish and German folklore [9].

Next Păcală inherits a cow, or a bull, and goes to the market to sell it. On his way he stops in the forest and sells his cow to a tree. Păcală gets upset because the tree would not answer him, or give him his money. Angrily, he hits the tree, and finds a treasure in its hollow. In the Western folklore the tree is replaced by a statue of a god or saint. In Aesop's fables one story relates how a man who asked Mercury's statue for money gets upset because the god does not seem to hear him, he breaks it and finds a treasure in the statue's head. In Cosquin's French collection Cadet Cruchon sells a piece of linen to a saint's statue, and because the saint does not want to pay him, he breaks the statue and finds a treasure. In the Neapolitan version Vardiello does the same thing, and Giufa from Sicily dye his linen green and sells it to a lizard; the treasure is then found in the lizard's house [10]. Remarkably, in the East European folklore this motif includes the cow/bull and the tree elements, whereas in the West European these elements are a saint statue and linen.

As the story goes on Păcală is hired by a priest to take care of his cattle (in some collections the story begins with this motif). The Trickster enters into a contract with his master: they agree to obey 
their deal until one of them gets angry, at which point the one who breaks the contract ought to be punished in various ways, most commonly, to have a piece of skin cut off his back, or to have his nose cut off. The Trickster starts immediately to do his malicious pranks, trying to force the priest to lose his patience. Some of his pranks are: making the priest and his wife dance until they are completely exhausted; while grazing the herds in the meadow he cuts a cow and eats it on the spot because the priest's wife doesn't give him any food; the next day he cuts a pig, than a lamb, and so on. Being told to clean the child, he does this is by peeling off the child's skin. When the wife tells him to cook a soup, and to add parsley to it, he also cooks the dog named Parsley.

In stories from Corsica, Picardia, SerboCroatia the priest from the Romanian folk story is replaced by a rich man or a king, who endure almost the same types of pranks. In the end the rich man or the king loses his patience, and gets punished [11].

In the Irish folklore the Trickster Pooka is considered essentially an animal spirit, whose name 'poc' means 'he-goat.' But he takes many shapes, horse, ass, bull, goat, etc. He could make a fine horse, but he has to be kept away from the sight of water, because he will plunge in with his rider and kill him. In an Irish folk story a piper meets with Pooka on his way to sing at a party; after a few spiteful pranks the Trickster gives him a pipe, and he becomes a famous piper [12].

The Scandinavian Peik gets horses and cattle from the bottom of the sea. Both, the Irish Pooka and the Scandinavian Peik have the magic flute that makes people dance until exhaustion. Peik is famous as a Trickster, whom the king always attempts to outsmart, but with no success [13].

The Trickster's name appears to be related to the Indo-European root * pek-. [14] which stands for livestock, domestic animal, cattle. It is possible that the Indo-European root is at the base of all these names: Pekulis, Patulos, Pooka, Pooc, Peik, Puc, Păcală, proving once more the incredible vitality of this character.

\section{Similarities and differences}

In comparing Hermes' actions with those of the Romanian Păcală, we can easily signal a number of conclusive similarities: the use of fire as a way please the divinity, the cows/animals sacrifice, the musical instrument, the fact that both take care of herds as shepherds, Hermes entrusted by Apollo with protecting his herds - Păcală hired as a shepherd. Both are supernatural characters tricking humans into trials. If Hermes' essential function is that of messenger of gods, in charge with bringing down the divine instruction, the Trickster may accomplish this task through his trial-pranks that actually may hide encoded messages. Playing the part of a catalyst the mythological character impacts the fortunes and behavior of the other gods. In folk stories the Trickster always puts an unsuspected fellow on trial with his tricks, bringing forward a moral message.

Besides similarities, there are some rather important differences between the two: Păcală doesn't steal the herd, while Hermes is entrusted with Apollo's herds after the boy steals (hides?) them from him. In the folk story the Trickster enters into a contract with the authority, and then starts his malicious pranks. Another difference to be observed is that Hermes as a god doesn't eat the meat he has sacrificed, whereas Păcală eats it. The significance of these differences may rest with the fact that ritualistic practices suffered modifications over time from myth to folklore.

\section{Tricksters position in the Indo-European Pantheon}

If we regard the main qualifications of the Trickster as a shepherd of flocks, or the association with sexual symbols, such as Hermes' phallic 'hermai' or Pekulis/Velnias showing his enormous phallus to women, the Trickster according to the Dumezilian Indo-European "class" system, represents the third class that governs wealth and fertility. Therefore the folk Tricksters, Păcală, Pooka, Peik, and ultimately the Lithuanian god Pekulis, belong to the agrarian pantheon, the third class function.

On the societal level the Trickster's pranks are addressed to the divine authority, Apollo or the other gods. In the West European folklore this divine authority is represented by the king of the land, or by the landlord. In the Eastern Europe the priest takes the function of divine authority. Parallel to the Trickster of ancient mythology who plays tricks on the other gods, the folk character 
plays tricks on the god's representative on Earth, the authority represented by a priest or a king. When the Trickster enters into a contract with the priest and forces him to break it, he maintains the judicial order, entering into the first class attributes as gods' messenger. Păcală always punishes the dishonest priest, the unfaithful wife, the thrifty fellow, and the perverts. $\mathrm{He}$ is in a permanent conflict with the bad spirits and the devil. He keeps the ethical order within the community. He seems to be closer in his vigilance to Varuna, the god who keeps a very sharp eye on every contract, and punishes bad behavior.

Why is this character playing tricks on the other gods? Is it because, as suggested by Gimbutas and others, he may be part of an older pantheon, a pre-Indo-European god? Due to lack of documentation such argument remains a speculation. Applying the Dumezilian classification we could argue that the Trickster's malicious pranks may be in some cases the result of his third function position. When he exposes the greediness and the stupidity of the king or the priest and their reaction through his pranks, the story enhances moral values within the social group, and the ethical and moral principles are transmitted from generation to generation.

\section{References}

1) Homeric Hymn 4 to Hermes. H. G. EvelynWhite, ed., http://www.perseus.tufts.edu/hopper/text?doc $=$ Perseus\%3Atext\%3A1999.01.0138\%3Ahy $\mathrm{mn} \% 3 \mathrm{D} 4$

2) Herodotus, Histories 2. 51. translation by A. D. Godley. Harvard University Press, Cambridge, 1920.

3) Gimbutas Marjia. The Balts. Frederick A. Praeger, New York: 1963

4) Puhvel, Jaan. Comparative Mythology. Johns Hopkins Univ. Press, Baltimore, London, 1987, 224.

5) Eliade, Mircea. Istoria Credintelor si Ideilor Religioase, Universitas, Chişinău, 1994.

6) Poetic Edda translated by Lee M. Hollander, University of Texas Press, Austin, 2nd ed., 1986.

7) Early Irish Myths and Sagas: translated with an introduction and notes by Jeffrey

Gantz,Penguin, 1981.
8) Dumezil, Georges. Mitra-Varuna; an Essay on Two Indo-European Representations of Sovereignty, Zone Books, New York, 1988.

9) Șăineanu, Lazăr. Basmele Române în comparaţiune cu legendele antice clasice. Minerva, Bucureşti, 1978.

10) Șăineanu, Lazăr. Ibidem.

11) Șăineanu, Lazăr. Ibidem.

12) Treasury of Irish Folklore. Ed. Padraic Colum, New York, 1954.

13) Scandinavian Folk and Fairy Tales. Edited by Claire Booss, Avenel Books, New York, 1984.

14) Pokorny, Julius. Indogermanisches etymologiscches worterbuch, Francke Verlag, Bern, 1959, 797. 